\begin{tabular}{|c|c|}
\hline Title & $\begin{array}{l}\text { Trawling experiment in a circular water tank to assess the effects of towing speed, light intensity, and mesh shape on } \\
\text { active escape of undersized fish }\end{array}$ \\
\hline Author(s) & Gabr, Mohamed; Fujimori, Y asuzumi; Shimizu, Susumu; Miura, Teisuke \\
\hline Citation & $\begin{array}{l}\text { Fisheries Science, 73(3), 557-564 } \\
\text { https://doi.org/10.1111/.1444 2906.2007.01368.x }\end{array}$ \\
\hline Issue Date & 2007-06-01 \\
\hline Doc URL & http:/hdl.handle.net/2115/55194 \\
\hline Rights & ○ 2007 公益社団法人日本水産学会; @ 2007 The Japanese Society of Fisheries Science \\
\hline Type & article \\
\hline File Information & DL_SF73(3)557-564.pdf \\
\hline
\end{tabular}

Instructions for use 


\title{
Trawling experiment in a circular water tank to assess the effects of towing speed, light intensity, and mesh shape on active escape of undersized fish
}

\author{
Mohamed GABR,* Yasuzumi FUJIMORI, Susumu SHIMIZU AND TeIsuke MIURA \\ Laboratory of Marine Environment and Resource Sensing, Graduate School of Fisheries Sciences, \\ Hokkaido University, Hakodate, Hokkaido 041-8611, Japan
}

\begin{abstract}
To assess the effect of towing speed and light intensity on the active escape of undersized fish through diamond and square mesh panels, a trawling experiment was simulated in a circular water tank. Juveniles of Japanese dace Tribolodon hakonensis (13-cm length class) were used as experimental fish. They were forced to swim inside a closed framed net with either diamond or square mesh (65-mm mesh size) that was moved using a speed-controllable motor. A submersible infrared CCD camera was used to observe and record the behavior of fish inside the net when it passed in front of the camera. Results indicated significant effects of towing speeds and light intensities $(P<0.05)$ on the escape of fish through the diamond and square meshes. Increase in light intensity enhanced the ability of fish to escape at lower towing speeds. At higher towing speeds, few fish could escape under light conditions. A strong negative correlation was found between towing speed and the frequency of fish escape (diamond mesh $R^{2}=0.99$, square mesh $R^{2}=0.96$ ). There was no significant difference between the numbers of fish escaping through the diamond and square meshes. These results suggest that the square-mesh panel may not be effective in the trawl cod end under dark or very low light intensity at high towing speed.
\end{abstract}

KEY WORDS: active escape behavior, diamond mesh panel, Japanese dace, light intensity, simulated trawling, square mesh panel, towing speed.

\section{INTRODUCTION}

The cod end is the main part of the trawl net where size selection generally occurs. ${ }^{1-5}$ Conventional trawl nets are constructed from netting of diamond-shaped meshes. Mesh shape collapses with increase in towing speed and catch size, and results in poor selectivity. This effect could be the reason that by-catch discards in trawl fisheries represent an important source of the large amount of the global fishery discards. ${ }^{6,7}$ The demand to conserve fish resources has persuaded fisheries scientists, management authorities, and fishing operators to use by-catch reduction devices to prevent, or minimize, the amount of by-catch. The square mesh panel is one of these by-catch reduction devices, which provides stable mesh openings that permit undersized fish to escape while retaining larger fish. ${ }^{8-10}$

${ }^{*}$ Corresponding author: Tel: 81-138-40-8832. Fax: 81-138-40-8832. Email: hosny@mailcity.com Received 26 May 2006. Accepted 12 January 2007.
Most fishes will avoid a net as an obstruction, and hesitate to pass through when they encounter it, even if the net has large enough mesh size to escape. The fish usually attempt to escape when they have been stimulated by visual and other senses. Glass et al. ${ }^{11,12}$ demonstrated that the frequency of fish escaping from square mesh panels increased by creating a visual illusion using a black tunnel in the cod end extension. However, the ambient light level controls this act of visual illusion; many researchers have mentioned that vision is important in stimulating fish to react in an ordered way to an approaching net. ${ }^{13-17}$

Despite the considerable success of the square mesh panel as a by-catch reduction device in various trawl fisheries, some authors have reported that the use of by-catch reduction methods that rely solely on mechanical separation in the cod end may lead to more undetectable mortality (escape mortality) of undersized fish. As a result, the total fish mortality will be underestimated. This in turn leads to much uncertainty in fish stock assessment that depends on such underestimated mortality 
coefficients. ${ }^{16,18,19,20}$ These authors have suggested that effective by-catch reduction devices should facilitate the rapid, active and safe escape of undersized and non-target fish from trawl nets. Hence, much attention has been given to the physical condition of fish escaping from trawl nets. Currently, the main premise for the use of by-catch reduction devices is to improve trawl selectivity and to assure survival of escaped fish., ${ }^{1,2,18,21-23}$

The behavior of undersized fish escaping through the meshes will influence the probability of survival and the efficiency of the escape panel as a size-selective by-catch reduction device. However, it is hard to examine precisely the relationship between the fish behavior and factors that affect fish escaping from a net by experiments in the sea. We therefore designed an experimental device in a circular water tank to simulate a trawl towing condition and assessed the behavior of undersized fish escaping through diamond and square mesh panels at different towing speeds and light intensities.

\section{MATERIALS AND METHODS}

\section{Experimental tank and fish used}

Since a large number of fish was necessary to confirm the availability of our experimental design, a freshwater fish was used in this study. Juveniles of Japanese dace Tribolodon hakonensis were chosen because of their high swimming ability. Two hundred fish were maintained in a rectangular fiberglass tank (length $240 \mathrm{~cm}$, width $100 \mathrm{~cm}$, height $70 \mathrm{~cm}$ ) for 2 weeks before the trials, which were in March and April 2005. The water temperature was maintained at $15^{\circ} \mathrm{C}$ using a thermostat in the holding rectangular and experimental circular tanks. Fish were fed with crumbled pellets. Total body length of the fish ranged $12-14 \mathrm{~cm}$, and almost all fish were classed into the $13-\mathrm{cm}$ length class $(12.5-13.5 \mathrm{~cm})$. Therefore, we chose fish from this class for the experiment $(n=120)$.

Schematics and dimensions of the experimental tank are shown in Figure 1. A speed-controllable motor (US 590-501C, Oriental Motor Co., Tokyo, Japan) was fitted over metallic boards at a central position over the circular tank. The framed net was set at the motor arm end and was rotated to simulate trawl towing. The motor was set so that it could be raised to bring the net door to the water surface for releasing fish inside the net. Two wooden bars were placed in both sides of the tank to diffuse water flow with movement of the framed net. This net was constructed from an aluminum frame and three kinds of netting panels (Fig. 2). For the ante-
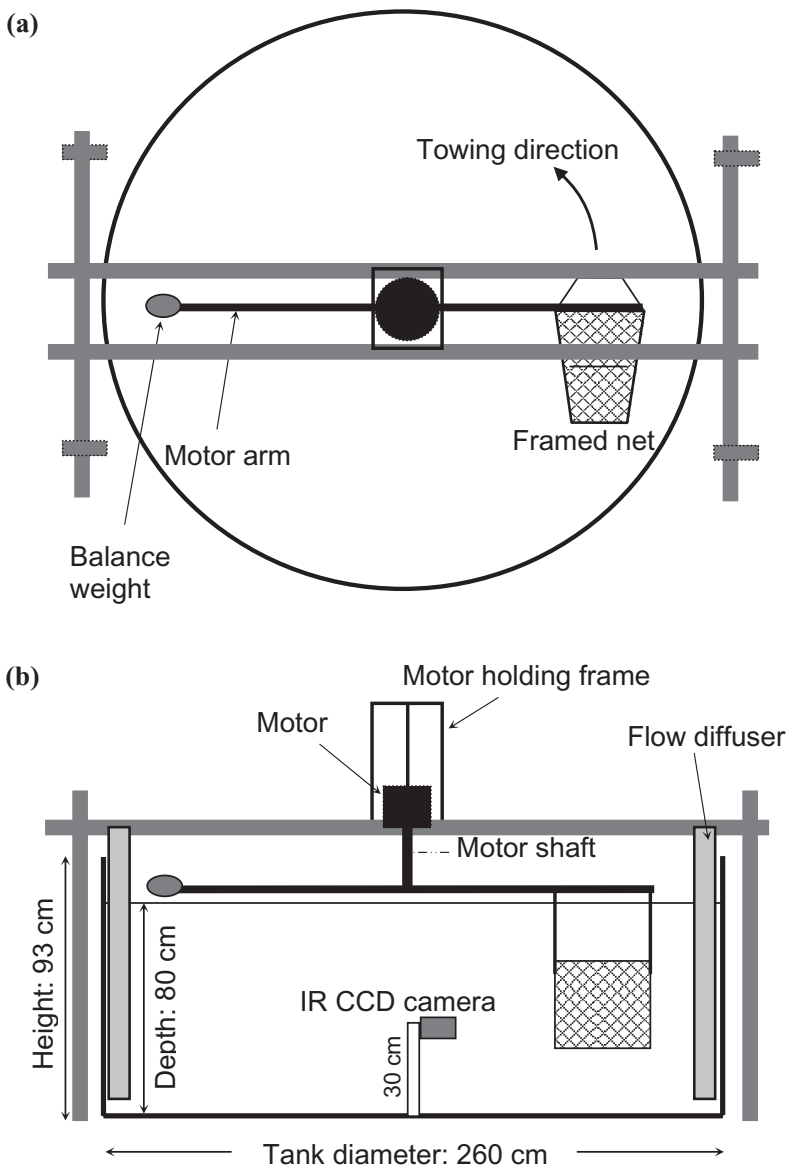

Fig. 1 Schematic drawings of the experimental tank and equipment, (a) top and (b) side views. IR CCD, infrared CCD camera.

rior part of the frame, a blue polyethylene mesh panel $(0.8 \mathrm{~mm}$ diameter, $30 \mathrm{~mm}$ mesh size) was used to reduce the light contrast of netting to the tank wall; for the posterior part, a white nylon panel (0.2 $\mathrm{mm}$ twine diameter, $20 \mathrm{~mm}$ mesh size) was used. Either the white polyethylene square mesh panel (Fig. 2) or diamond mesh panel $(1.8 \mathrm{~mm}$ twine diameter, $65 \mathrm{~mm}$ mesh size) was installed in the middle of the framed net as the escape panel. For the diamond mesh panel, the hanging ratio was set to 0.85 and the vertical mesh opening width was $34.6 \mathrm{~mm}$. The separating panel was set at the boundary between the anterior and posterior space so that the fish were in the posterior space until observation of fish escaping started. The separating panel could be opened downward during movement of the framed net to allow fish movement toward the escape panel, which was operated from the outside of the tank. Figure 3 shows fish movement with the opening of the separating panel. A waterproof color infrared CCD camera (TR-851WCP, Corona-Dengyo, Tokyo, Japan) was 
(a)

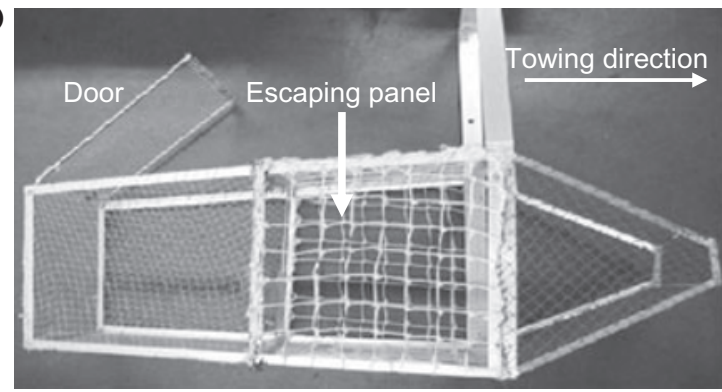

(b)
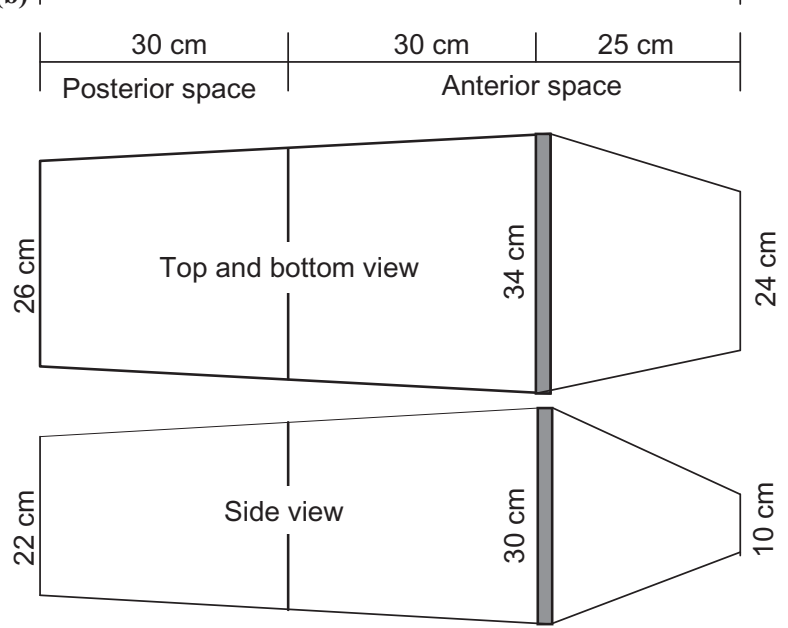

Fig. 2 Framed net used in the experiment. (a) Sideview photograph, and (b) schematic diagrams.

fixed to the bottom of the tank. This camera was connected to a portable video recorder with a liquid-crystal display (LCD) TV (VF-5SR, Casio, Tokyo, Japan) to record fish behavior inside the framed net when it passed in front of the camera.

\section{Towing speed and light intensity}

The towing speed of the framed net was changed with the motor controller and was estimated by dividing the movement distance $(\mathrm{cm})$ in one revolution by the time (seconds). This distance was calculated as the perimeter of a circle of 1-m radius, which was the distance between the motor shaft and the center of the net. Four towing speeds were applied in this experiment: $30,60,90$, and $110 \mathrm{~cm} / \mathrm{s}$. The water current speed created by the net movement was measured using a micro data logger (W350L-PDT, Little Leonard, Tokyo, Japan). The speed was below the sensitivity of the current meter $(17 \mathrm{~cm} / \mathrm{s})$. Water flow inside the net was assumed to be equal to the corresponding towing speed, because it was difficult to measure. (a)

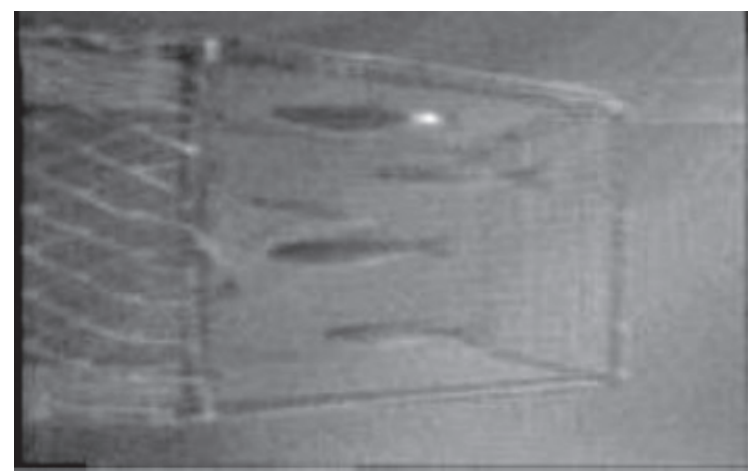

(b)

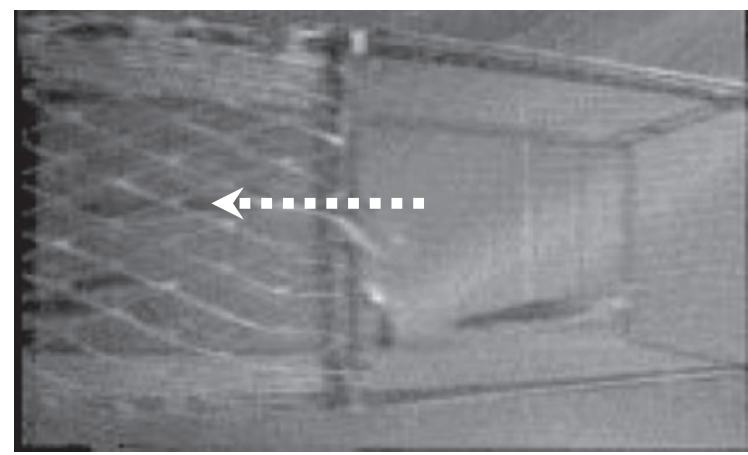

Fig. 3 Fish movement as separating panel is opened. (a) Five fish wait at the posterior space, (b) fish move to the anterior space after the separating panel is opened downward; white arrow shows direction of fish movement. Photographs were recorded using a halogen light flash.

The light sources were a fluorescent lamp and halogen lamp. The water tank was covered with a vinyl sheet during the experiment to prevent change in light intensity from the influence of any reflection. The light intensity of both lamps (switched on together) at the water surface under the cover was $23 \mathrm{~lx}$; the light intensity of the halogen lamp was only $6.0 \mathrm{~lx}$, which could be decreased gradually by reducing the voltage. Five levels of light intensity were applied in the experiment: 23, 6.0, 2.0, $0.2 \mathrm{~lx}$, and complete dark $(<0.003 \mathrm{~lx})$. A light intensity logger (StowAway LI, Onset Computer Co., Bourne, MA, USA) was used to measure the light intensity in lumens per square feet and then converted into lux. The minimum recorded light intensity under dark was $0.003 \mathrm{~lx}$. This value was equal to the lower limit of the logger sensitivity. Therefore, the real light intensity under dark may have been lower than this value.

\section{Experimental procedure}

The experiment was performed for the diamond and square mesh panels with different towing 


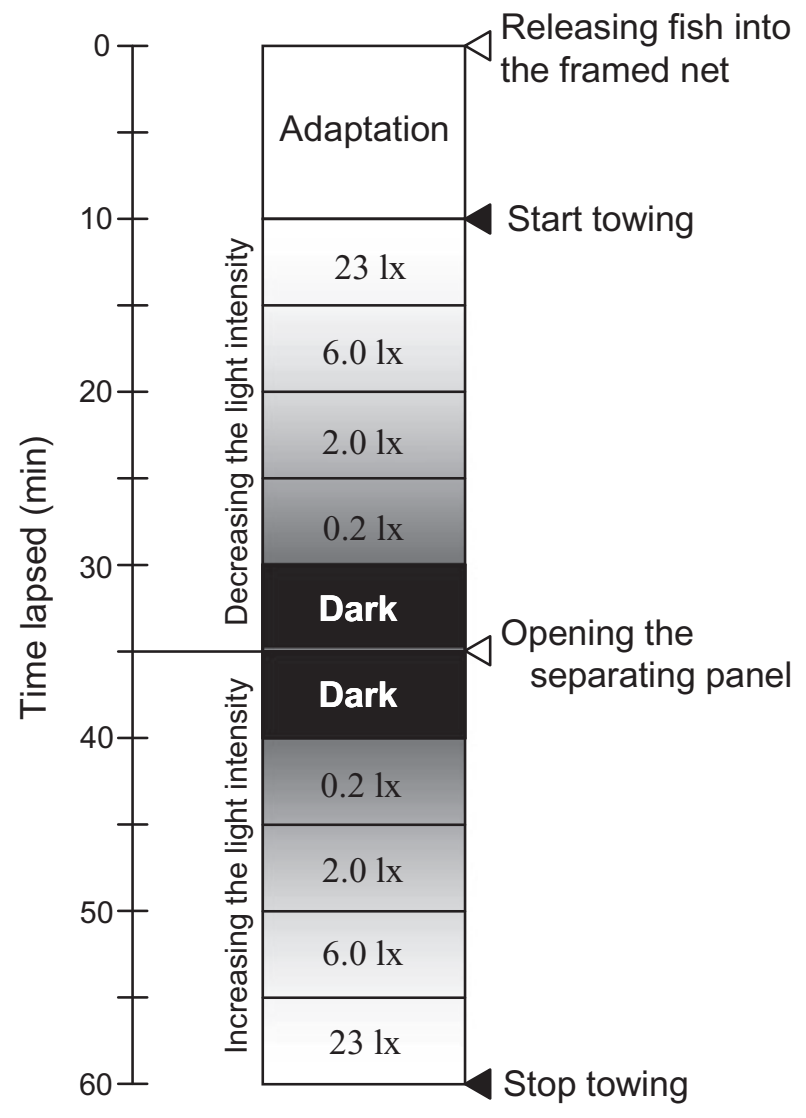

Fig. 4 Experimental procedure for each trial.

speeds, changing the light intensity, and replicated three times in the same conditions. The experimental sequence is shown in Figure 4. At first, five fish were moved from the holding tank to the framed net in the experimental tank. Fish were left for 10 min for adaptation in the framed net. The space inside the net was large enough for the five fish to swim without interaction or crowding. After adaptation, towing was started under the light condition (23 lx), and the light intensity was decreased gradually every five minutes until completely dark $(<0.003 \mathrm{~lx})$. At the end of the dark condition, the separating panel was opened and the light intensity was increased (Fig. 4). Fish escaping were observed during the condition of increasing light intensity (starting from dark) because typically the adaptation of fish's eye to increasing light (light adaptation) is more rapid than its adaptation to decreasing light (dark adaptation). At the end of each light intensity period, the numbers of fish still swimming inside the net, and of fish escaped, were recorded. Under complete dark condition, a light flash was generated for one second by a halogen lamp to record fish behavior when the net passed in front of the camera.

\section{Data analysis}

After accumulating data from the same experimental conditions, the escape results were grouped into two randomized block tables for the diamond and square mesh panels, respectively. Each block represents the ratio (and the number in parentheses) of fish escaping during each light intensity (total of three trials at each towing speed). Since the sample size at the start of each trial decreased because some fish escaped, the number of fish inside the net at the beginning of each light level was considered as the sample size for that light level.

Friedman non-parametric two-way analysis of variance (ANOVA) was used to test the effect of towing speed over light intensity levels and vice versa on fish escaping through the diamond and square mesh panels. Kruskal-Wallis one-way ANOva was used to examine the effect of mesh shape on fish escape at different towing speeds. Additionally, linear regression analysis was performed between the towing speed (as the independent variable) and the corresponding total escape ratio (as the dependent variable). For these analyses, the statistical software STATISTIX v8.1 (Analytical Software, Tallahassee, FL, USA) was used.

\section{RESULTS}

The results of fish escaping through the diamondmesh panel are shown in Table 1. The Friedman non-parametric two-way ANOva showed a significant effect of towing speed (Friedman statistic $=11.195, \quad P$-value using $\chi^{2}$-approximation $=$ $0.0107<0.05$ ) and a significant effect of light intensity (Friedman statistic $=11.015, \quad P$-value using $\chi^{2}$-approximation $=0.0264<0.05$ ). Figure $5 \mathrm{a}$ shows the regression equation and relationship between the towing speed and the corresponding total percent of fish escaping through the diamond-mesh panel. There was a strong negative correlation between the towing speed and fish escape $\left(R^{2}=0.99\right)$.

Table 2 shows the results of fish escaping through the square-mesh panel. Friedman non-parametric two-way ANova revealed significant effect of towing speed (Friedman statistic $=8.132, \quad P$-value using $\chi^{2}$-approximation $=$ $0.0434<0.05)$ and a significant effect of light intensity (Friedman statistic $=10.085, P$-value using $\chi^{2}$-approximation $\left.=0.039<0.05\right)$. The regression equation and relationship between towing speed and the corresponding total frequency of fish 
Table 1 Fish escape ratio (\%) for diamond-mesh panel at different towing speeds and light intensities

\begin{tabular}{|c|c|c|c|c|}
\hline \multirow[b]{2}{*}{ Light intensity (lx) } & \multicolumn{4}{|c|}{ Towing speed $(\mathrm{cm} / \mathrm{s})$} \\
\hline & 30 & 60 & 90 & 110 \\
\hline$<0.003$ & $13.3(2)$ & 0 & 0 & 0 \\
\hline 0.2 & $15.4(2)$ & 0 & 0 & 0 \\
\hline 2.0 & 9.0 & $6.7(1)$ & 0 & 0 \\
\hline 6.0 & 10.0 & $21.4(3)$ & 0 & $6.7(1)$ \\
\hline 23 & $77.8(7)$ & $54.5(6)$ & $33.3(5)$ & $14.3(2)$ \\
\hline$\%$ Total fish escaped & 87.0 (13) & $66.7(10)$ & $33.3(5)$ & $20.0(3)$ \\
\hline$\%$ Total fish retained & $13.0(2)$ & $33.3(5)$ & $66.7(10)$ & $80.0(12)$ \\
\hline
\end{tabular}

Values in parentheses, numbers of fish escaped.

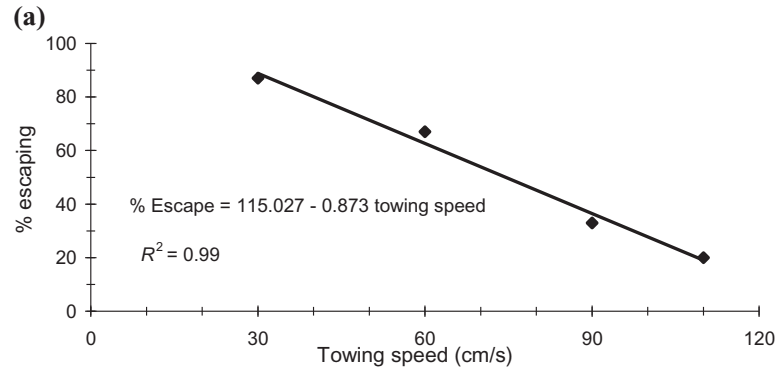

(b)

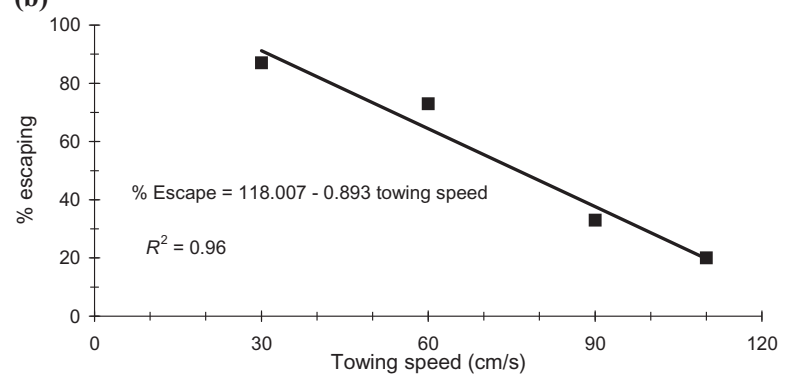

(c)

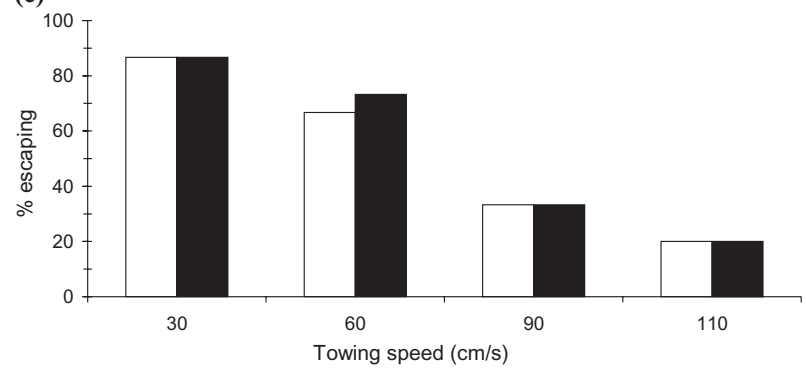

Fig. 5 Linear regression results between towing speed and frequency of fish escape through (a) diamond mesh panel $(\diamond) ; \%$ escape $=115.027-0.873 \times$ towing speed, $R^{2}=0.99$, and (b) square-mesh panel (ם); \%escape $=118.007-0.893 \times$ towing speed, $R^{2}=0.96$; solid lines, predicted values. (c) Comparison of the frequency of fish escaped between the diamond ( $\square$ ) and square ( $\square$ ) mesh panels by towing speed.

escaping through the square-mesh panel are shown in Figure 5b. There was a strong negative correlation between the towing speed and fish escape $\left(R^{2}=0.96\right)$.
Figure $5 \mathrm{c}$ shows the total frequency of fish escaping through the diamond and square mesh panels at different towing speeds. The Kruskal-Wallis one-way ANOva revealed no significant difference between fish escaping through the diamond meshes and that through the square meshes at different towing speeds (Kruskal-Wallis statistic $=0.0216, \quad P$-value using $\chi^{2}$-approximation $=$ 0.8831 ).

Fortunately, we could record two complete escape events through the mesh panels under the light conditions. Figure 6 shows fish escaping through the diamond mesh panel at a towing speed of $60 \mathrm{~cm} / \mathrm{s}$ under $23 \mathrm{~lx}$ (Fig. 6a) and through the square mesh panel at a towing speed of $90 \mathrm{~cm} / \mathrm{s}$ under $2.0 \mathrm{~lx}$ (Fig. 6a). The time required penetrating the diamond mesh, which started when the fish turned its head into the mesh and lasted until its caudal fin exited from the mesh, was estimated as $0.56 \mathrm{~s}$ on a frame-by-frame calculation (the duration of each frame was 1/30 s). Moreover, we confirmed that these fish pass through the mesh without touching the twines. This observation implies that the fish could swim $23 \mathrm{~cm} / \mathrm{s}$ faster than the towing speed of $60 \mathrm{~cm} / \mathrm{s}$. The fish swimming speed for mesh penetration was estimated to be $83 \mathrm{~cm} / \mathrm{s}(60+23 \mathrm{~cm} / \mathrm{s})$. The time of the square mesh penetration in the second escape event was $0.43 \mathrm{~s}$. Similarly, swimming speed of the fish for penetrating the mesh was estimated to be $120 \mathrm{~cm} / \mathrm{s}(90+30 \mathrm{~cm} / \mathrm{s})$.

\section{DISCUSSION}

The active escape of juvenile Japanese dace correlated strongly with the light intensity and the towing speed. Increase in the light intensity increased the ability of fish to escape at lower towing speeds. At higher towing speeds, however, few fish could escape under light conditions. Although fish could sustain the swimming 
Table 2 Fish escape ratio (\%) for square-mesh panel at different towing speeds and light intensities

\begin{tabular}{|c|c|c|c|c|}
\hline \multirow[b]{2}{*}{ Light intensity (lx) } & \multicolumn{4}{|c|}{ Towing speed $(\mathrm{cm} / \mathrm{s})$} \\
\hline & 30 & 60 & 90 & 110 \\
\hline$<0.003$ & 0 & 0 & 0 & 0 \\
\hline 0.2 & $26.4(4)$ & $6.7(1)$ & 0 & $13.3(2)$ \\
\hline 2.0 & $18.2(2)$ & 0 & $6.7(1)$ & 0 \\
\hline 6.0 & 11.1 & 7.1 (1) & 0 & 0 \\
\hline 23 & $75.0(6)$ & $69.2(9)$ & $28.6(4)$ & 7.7 (1) \\
\hline$\%$ Total fish escaped & $87.0(13)$ & $73.3(11)$ & $33.3(5)$ & $20.0(3)$ \\
\hline$\%$ Total fish retained & $13.0(2)$ & $26.7(4)$ & $66.7(10)$ & $80.0(12)$ \\
\hline
\end{tabular}

Values in parentheses, numbers of fish escaped.

(a)

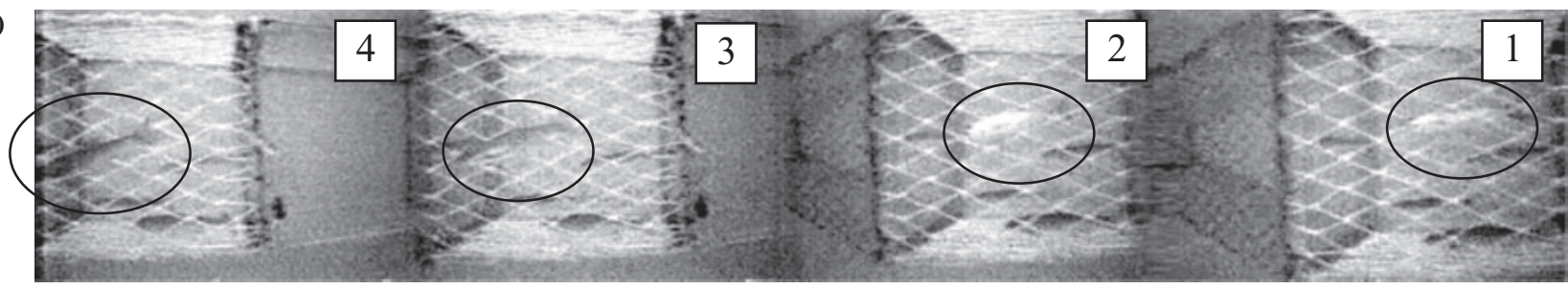

(b)

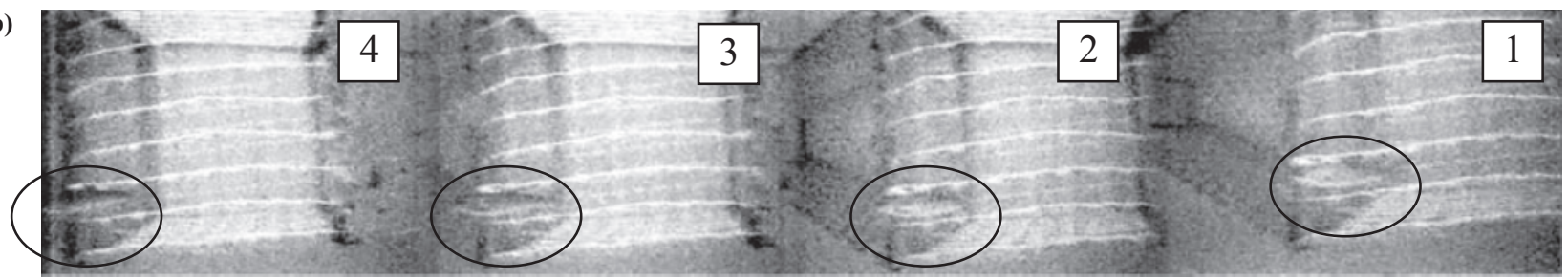

Fig. 6 Photographs of fish that escaped through (a) the diamond mesh panel at a towing speed of $60 \mathrm{~cm} / \mathrm{s}$, and (b) the square mesh panel at a towing speed of $90 \mathrm{~cm} / \mathrm{s}$. Numbers show the order of frames; ellipse outlines indicate escaping fish.

direction inside the net under dark and very low light intensities, which was possibly executed using their inner ear for spatial orientation, ${ }^{24}$ fish could not escape from the mesh panel under such conditions and showed minimum escape response. Thus, vision plays an important role in the active escape of fish. This result agrees with those given in previous studies, which mentions that in the absence of vision under dark or low light level, either fish are unable to react in an orderly manner towards an approaching trawl net, ${ }^{13,14}$ or can not swim to maintain their position in a trawl net. ${ }^{15,16}$ Ryer and $\mathrm{Olla}^{17}$ reported that juvenile walleye pollock are more likely to strike an approaching net under such a condition.

The linear regression analysis showed a strong negative correlation between the towing speed and the frequency of fish escaping through the diamond and square-mesh panels. According to the linear equations shown in Figure 5a,b, Japa- nese dace in the 13-cm length class cannot escape through the mesh regardless of the mesh shape when the towing speed exceeds $132 \mathrm{~cm} / \mathrm{s}$, which is approximately 10 times their length. $\mathrm{He}^{25}$ reported that the swimming speed required for a fish to escape from the cod end of a trawl net is related to the mesh size, fish length, body geometry, and the towing speed of the net. In our experiment, the mesh size used and the hanging ratio applied for the diamond mesh panel were thought to be large enough for the fish to escape, because all fish could escape easily through the mesh panel after the towing finished. Hence, the only factor that deters the fish from escaping under light conditions would be the towing speed relative to the swimming ability of the fish.

In our experiment, two complete escape events were recorded. The analysis of these two events may explain why fish could not escape at higher towing speeds, even under light conditions. 
Although the number of cases recorded may not be enough for analysis, it is clear that the swimming speed must be higher than the towing speed when fish escape from the mesh. For the diamond mesh panel (towing speed $60 \mathrm{~cm} / \mathrm{s}$ ), the swimming speed at which fish escaped through the mesh was estimated to be $83 \mathrm{~cm} / \mathrm{s}$, and for the square mesh panel (towing speed $90 \mathrm{~cm} / \mathrm{s}$ ), the speed was estimated to be $120 \mathrm{~cm} / \mathrm{s}$. The ratios of each escaping speed to the towing speed are 1.38 and 1.33, respectively. Usually, the towing speed of commercial fishing is determined to catch adult fishes, which should be higher than or at least equal to their maximum swimming ability. Consequently, undersized fish may not be able to sustain their position or orient themselves to actively escape regardless of mesh shape under real trawling conditions of low light intensity and high towing speed, because undersized fish have lower swimming ability and endurance than adult fish. ${ }^{25-28}$

Our results revealed no significant relation between mesh shape and fish escaping at different towing speeds. Bullough et al. ${ }^{29}$ demonstrated that fitting the square mesh panel did not appreciably improve the overall selectivity of the cod end of a commercial demersal trawl. $\mathrm{He}^{30}$ found no significant effect of mesh shape (diamond or square cod end) on the retention length $\left(\mathrm{L}_{50}\right)$ for roundfish (cod and haddock) in bottom trawling in the Gulf of Maine. These results show that the effect of mesh shape on fish escape may not differ even when the diamond mesh opens as planned. However, it is known that the diamond mesh opening changes with increase in tension of netting. ${ }^{3} \mathrm{O}^{\prime}$ Neill et al. ${ }^{31}$ referred to an improved size-selectivity of the diamond mesh cod end under sea conditions. They pointed out that rough sea conditions cause large motion of vessels from rocking waves, which in turn produces a longitudinal pulsing movement of the cod end. This movement leads to cyclic changes in the opening of the diamond mesh and water velocity inside the cod end, which increases the probability of escape of undersized fish. In such a case, the use of a square mesh panel may present more stable wide openings, which would further increase the probable escape of undersized fish in the light condition only. Fish may not escape actively under dark conditions, even at lower towing speeds, as indicated by results of this experiment. However, Kim and Wardle ${ }^{32}$ note that erratic fish behavior may increase the probability of fish escaping through cod end meshes. If this behavior occurred under dark conditions, fish may have a higher probability of damage and unobserved mortality. Undersized fish are more likely to experience the most harmful effects during this kind of escape.

\section{CONCLUSION}

Our results demonstrated that the active escape of undersized fish through diamond and square mesh panels depends on the light intensity and towing speed, with no significant difference in escape levels between the diamond and square mesh panels. The square mesh panel, therefore, may not be effective for reducing undersized fish by-catch when used under dark conditions and high towing speeds, which are common trawling conditions for most finfish trawl fisheries. ${ }^{16,17}$ However, further investigation using a species targeted by trawl fisheries is needed to ascertain this propensity.

During further investigations, the camera ought to be set in the framed net to record fish behavior continuously, although such a setting is practically difficult because of the existence of camera cable. Such a device and a more sensitive camera would allow thorough observation of escape behavior and various reactions. Further, only small fish $(<20 \mathrm{~cm}$ total length) could be used because larger fish suffer more stress from the curved swimming track than small fish. This effect increases as the radius of the curved swimming track decreases. ${ }^{33}$

\section{ACKNOWLEDGMENTS}

M.G. thanks the Mission Department, Ministry of Higher Education of the Egyptian Government, for supporting Ph.D. study in the Graduate School of Fisheries Sciences, Hokkaido University. The authors thank laboratory colleagues for help during the experiment.

\section{REFERENCES}

1. DeAlteris JT, Reifsteck DM. Escapement and survival of fish from the codend of a demersal trawl. ICES Mar. Sci. Symp. 1993; 196: 128-131.

2. Isaksen B, Valdemarsen JW. Bycatch reduction in trawls by utilizing behaviour differences. In: Fernö A, Olsen S (eds). Marine Fish Behaviour in Capture and Abundance Estimation. Fishing News Books, London. 1994; 69-83.

3. Wileman DA, Ferro RST, Fonteyne R, Millar RB. Manual of methods of measuring the selectivity of towed fishing gears. ICES Cooperative Research Report No. 215. ICES, Copenhagen. 1996.

4. Bethke E. A simple general approach to codend selectivity of trawls and its application to data of Fiorentio et al. (1998) for hake (Merluccius merluccius). Fish. Res. 2004; 70: 113119.

5. Herrmann B. Effect of catch size and shape on the selectivity of diamond mesh cod-ends. I. Model development. Fish. Res. 2005; 71: 1-13. 
6. Alverson DL, Freeberg MH, Murawasaki SA, Pope JG. A global assessment of fisheries bycatch and discards. FAO Fisheries Technical Paper No. 339. FAO, Rome. 1994.

7. Kelleher K. Discards in the world's marine fisheries: an update. FAO Fisheries Technical Paper No. 470. FAO, Rome. 2005.

8. Larsen R, Isaksen B. Size selectivity of rigid sorting grids in bottom trawls for Atlantic cod (Gadus morhua) and haddock (Melanogrammus aeglefinus). ICES Mar. Sci. Symp. 1993; 196: 178-182.

9. Madsen N, Holst R, Foldager L. Escape windows to improve the size selectivity in the Baltic cod trawl fishery. Fish. Res. 2002; 57: 223-235.

10. Graham N, Kynoch RJ, Fryer RJ. Square mesh panels in demersal trawls: further data relating haddock and whiting selectivity to panel position. Fish. Res. 2003; 62: 361-375.

11. Glass CW, Wardle CS. Studies on the use of visual stimuli to control fish escape from codends II. The effect of a black tunnel on the reaction behaviour of fish in otter trawl codends. Fish. Res. 1995; 23: 165-174.

12. Glass CW, Wardle CS, Gosden SJ, Racey DN. Studies on the use of visual stimuli to control fish escape from codends I. Laboratory studies on the effect of a black tunnel on mesh penetration. Fish. Res. 1995; 23: 157-164.

13. Glass CW, Wardle CS. Comparison of the reactions of fish to a trawl gear, at high and low light intensities. Fish. Res. 1989; 7: 249-266.

14. Walsh SJ, Hickey WM. Behavioral reactions of demersal fish to bottom trawls at various light conditions. ICES Mar. Sci. Symp. 1993; 196: 68-76.

15. Olla BL, Davis MW, Schreck CB. Effects of simulated trawling on sablefish and walleye pollock: the role of light intensity, net velocity and towing duration. J. Fish Biol. 1997; 50: 1181-1194.

16. Olla BL, Davis MW, Rose C. Differences in orientation of walleye pollock Theragra chalcogramma in a trawl net under light and dark conditions: concordance between field and laboratory observations. Fish. Res. 2000; 44: 261-266.

17. Ryer CH, Olla BL. Avoidance of an approaching net by juvenile walleye pollock Theragra chalcogramma in the laboratory: the influence of light intensity. Fish. Res. 2000; 45: 195-199.

18. Chopin FS, Arimoto T. The condition of fish escaping from fishing gears - a review. Fish. Res. 1995; 21: 315-327.

19. Davis MW. Key principles for understanding fish bycatch discard mortality. Can. J. Fish. Aquat. Sci. 2002; 59: 18341843.
20. Ryer CH, Ottmar ML, Sturm EA. Behavioral impairment after escape from trawl codends may not be limited to fragile fish species. Fish. Res. 2004; 66: 261-269.

21. Ryer $\mathrm{CH}$. Trawl stress and escapee vulnerability to predation in juvenile walleye pollock: is there an unobserved bycatch of behaviorally impaired escapees? Mar. Ecol. Prog. Ser. 2002; 232: 269-279.

22. Suuronen P, Perez-Comas JA, Lethonen E, Tschernij V. Sizerelated mortality of herring (Clupea harengus L.) escaping through a rigid sorting grid and trawl codend meshes. ICES J. Mar. Sci. 1996; 53: 691-700.

23. Suuronen P. Mortality of fish escaping trawl gears. FAO Fisheries Technical Paper No. 478. FAO, Rome. 2005.

24. Pavlov DS, Tjurjukov SN. Reactions of dace to linear accelerations. J. Fish Biol. 1995; 46: 768-774.

25. He P. Swimming speeds of marine fish in relation to fishing gears. ICES Mar. Sci. Symp. 1993; 196: 183-189.

26. Wardle CS, He P. Burst swimming speeds of mackerel, Scomber scombrus L. J. Fish Biol. 1988; 32: 471-478.

27. Nikora VI, Aberile J, Biggs BJF, Jowett IG, Sykes JRE. Effect of fish size, time-to-fatigue and turbulence on swimming performance: a case study of Galaxias maculates. J. Fish Biol. 2003; 63: 1365-1382.

28. Breen M, Dyson J, O’Neill FG, Jones E, Haigh M. Swimming endurance of haddock (Melanogrammus aeglefinus L.) at prolonged and sustained swimming speeds, and its role in their capture by towed fishing gears. ICES J. Mar. Sci. 2004; 61: 1071-1079.

29. Bullough LW, Napier IR, Laurenson CH, Riley D, Fryer RJ, Ferro RST, Knoch RJ. A year-long trial of a square mesh panel in a commercial demersal trawl. Fish. Res. 2007; 83: 105-112.

30. He P. Selectivity of large mesh trawl codends in the Gulf of Maine. I. Comparison of square and diamond mesh. Fish. Res. 2007; 83: 44-59.

31. O’Neill FG, McKay SJ, Ward JN, Strickland A, Kynoch RJ, Zuur AF. An investigation of the relationship between sea state induced vessel motion and codend selection. Fish. Res. 2003; 60: 107-130.

32. Kim Y-H, Wardle CS. Optomotor response and erratic response: quantitative analysis of fish reaction to towed fishing gears. Fish. Res. 2003; 60: 455-470.

33. He P, Wardle CS. Endurance at intermediate swimming speeds of Atlantic mackerel, Scomber scombrus L., herring, Clupea harengus L. \& saithe, Pollachius virens L. J. Fish Biol. 1988; 33: 255-266. 